\title{
Nima Yushij's "Afsaneh" as a Striking Exemplar of the 'Greater Romantic Lyric'
}

\author{
Mohammad Hussein Oroskhan ${ }^{1 *}$, Esmaeil Zohdi ${ }^{2}$ \\ ${ }^{* 1}$ M.A. Scholar, Department of English Literature, Faculty of Humanities, Vali-e-Asr University, \\ Rafsanjan, Kerman, Iran \\ Email: h.araskhan@yahoo.com \\ ${ }^{2}$ Assistant Professor, Department of English Literature, Faculty of Humanities, Vali-e-Asr \\ University, Rafsanjan, Kerman, Iran \\ Email: esmaeil_zohdi@yahoo.com
}

Keywords: The greater romantic lyric, Romanticism, Lyric, Nima's "Afsaneh"

\begin{abstract}
Persian poetry lingered upon the old classical Persian prosody for more than a thousand year that it stagnated and stopped flowering new concepts and forms. However, Nima broke the dull and monotonous routine of Persian poetry by writing the first true modernist poem. When Nima's "Afsaneh" appeared, traditionalist adamantly opposed its new artistic and aesthetic view due to revealing some similarity with great European romantic examples. The similarity can never be considered as a weak point of "Afsaneh" because Nima has masterfully used European romantic elements to refresh the long-standing tradition of Persian poetry. In this respect, Nima has written his poetry consciously or unconsciously in the same poetic style of great European romantic poets. M. H. Abrams has labeled this poetic style "the greater romantic lyric". As a result, it is tried to examine Nima's "Afsaneh" with respect to Abrams's definition of "the greater romantic lyric" so as to prove that Nima's "Afsaneh" closely conform to this new poetic genre.
\end{abstract}

\section{INTRODUCTION}

Defining the concept of romanticism is undoubtedly among one of the most controversial concept of literary schools. By the beginning of twentieth century, many literary theories spent a great deal of time to deal with this issue. It has even baffled some critics like the American scholar Arthur Lovejoy to the extent that he observed romanticism as a word which "has come to mean so many things that, by itself, it means nothing" (1965, p.232). Indeed, he deeply pondered upon this view that for a time he tried to willfully accept the concept that "Romanticism is that the name of it offers one of the most complicated, fascinating, and instructive of all problems in semantics" (1965, p.235). He justified his view on the grounds that romanticism is not only consisted of "in part heterogeneous ideas (1965, p. 236)" but also dominated by "logically independent, and sometimes essentially antithetical ideas (1965, p. 236)" that makes it impossible to offers a precise definition of this term.

In this attempt of defining the term "romanticism", all were not as skeptical as Lovejoy. Indeed, Rene Wellek attempted to unify these disparate ideas and demarcate its boundaries. One can be notified of his convergent view by considering the title of his article which is "The Concept of 'Romanticism' in Literary History II. The Unity of European Romanticism". In trying to define romanticism, he truly succeeded in his attempt as he came up with a trio-feature for romanticism in all European country:

If we examine the characteristics of the actual literature which called itself or was called 'Romantic' all over the continent, we find throughout Europe the same conception of poetry and of the workings and nature of poetic imagination, the same conception of nature and its relation to man, and basically the same poetic style; with a use of imagery, symbolism, and myth, which is clearly distinct from that of 18 th century NeoClassicism. $(1949$, p.147) 
Nonetheless, the central aim of this paper is not to reach a consensus over the definition of the term 'romanticism'. Two main theorist of this field were mentioned above, on the other hand, many other theorist have also contributed to this field. Even mentioning all of them would exhaust the capacity of more than one paper. In this case, we are forced to leave pondering over the notion of romanticism which is "a hazardous occupation which has claimed many victims" (Burgum, 1941, p.479) and direct our attention to the main aim of this paper which is regarding the concept of romanticism and the form in which it is expressed. This could be easily seen that these two areas are so closely interconnected that they are grown together and promotes a complete unity. As a result, the form of a particular genre is not a sole criterion to be selected by the poet in advance whereas the poet's relation with the subject shapes the form "the poet's relationship to the world defines the genre in which he is working....In fact, one can easily put together a theory of romanticism from a virtually random selection of passages by any given poet or group of poets (Lindenberger, 2009, p. 30)" because based upon "a privileged artistic form for the romantics, theories of romanticism are generally stitched together out of fragments of diverse writing, both verse and discursive prose". . (2009, p. 35).

Lindenberger's argument serves to emphasize the interconnected relation between the theory of romanticism and its form. In other word, one should not assume the structure of a poem as a range of formal devices, but rather as a sequence of actions in the speakers' mind which comprises at once the form and the content of the poem. This unification takes a very leading role in M.H Abrams' seminal essay "Structure and Style in the Greater Romantic Lyric."

Abrams has thoroughly discussed the poetic mode of English romanticism in his essay. And though it has been published for forty years, it is considered a touchstone in the realm of literary romantic criticism; "Abrams's account of the introspective and meditative aspects of Romantic lyric remains a model of concision and elegance that continues to orient the study of Romantic poetry" (Chandler, 2009, p. 1).

In his essay, Abrams follows the tradition of Romantic lyric from mid-seventeenth and eighteenth century verse of Denham's "Cooper's Hill" (1642/55) and Gray's "Ode on a Distant Prospect of Eton College" (1747) to the great examples of Coleridge's "The Eolian Harp," Wordsworth's "Tintern Abbey," and Keats's "Ode to a Nightingale" which are among the prototypes of English romanticism. By describing these famous poems, he derives out a new form out of the tradition of English romanticism. He has called this new form "the greater romantic lyric". Abrams' coinage of this new term has provided us with a new perspective for studying not only English romanticism but also examining the poetic style romanticism throughout the world.

Nonetheless, the aim of this study is to explore Abrams' theoretical essay not in English romanticism but far from that place in Western Asia (Iran). Around 1920s, Nima Yushij, a young poet, began rebelling against the oppressive traditional rule of classical Persian literature. His sustained mental effort resulted in writing 'Afsaneh' meaning legend. Moreover, the cogent reason behind selecting Nima's 'Afsaneh' for such a study is that "Nima's romanticism represents the culmination of romanticism in Persian literary history (Jaffari, 2007, p.200)". Furthermore, his poem 'Afsaneh' is the "most distinguished Nima's poem in romanticism"(Jaffari, 2007, p.237). As a result, our attempt is to consider Nima's 'Afsaneh' based on Abrams' theoretical perspective so as to demonstrate another attractive aspect of Nima's poetry by putting it in Western context.

\section{DISCUSSION}

\section{Nima's 'Afsaneh'}

Nima Yushij (1897-1960) was born in a small city named Yush near Rasht. His works have long marked a turning point in the Persian literary history. His blatant and determined attempt to break the monotonous routine rules of Classical Persian literature succeeded when he wrote 'Afsaneh' in 1922. In fact, along this long path, his acquaintance with French language bolstered his confidence and brought him substantial benefit: 
The short lyrical pieces of French poetry Nima had read at St. Louis, works by Lamartine, Hugo, Mallarme, did present a contrast to the exhortative rhetoric, ordered sonority, and lexical simplicity typical of the Khorasani School poetry current in the early centuries of Islamic Iran and still in vogue through the first half of the twentieth century (Karimi Hakkak, 2004, p.29).

Observing Nima's acquaintance with French language and poetry, a crucial point is raised. Indeed Nima was not only acquainted with French language whereas he was familiarized with French romanticism. This could truly justify why Masoud Jaffari, the notable author of $A$ Survey of Romanticism in Iran: From Constitutional Revolution to Nima, has exclusively devoted half of his book to Nima's romanticism. In Jaffari's view, "Nima's romanticism is separated from the two common types of emotive and nationalistic romanticism of its previous time and it is mainly natureoriented. In any case, Nima's romanticism represents the culmination of romanticism in Persian literary history" (2007, p. 200). This acquaintance formed a watershed in Nima' life and its effect can be felt in his poetry specifically 'Afsaneh'. Also different studies have been undertaken in bearing the relation between Nima's 'Afsaneh' and French romanticism. In this respect, Arianpour in his book, From Saba to Nima, expresses that the cumulative impact of French poets notably Lamartine and Musset can be felt in 'Afsaneh' (2008, p.471) or Abdol Hussein Zarinkoob in his book, Not Oriental Nor Occidental, regards 'Afsaneh' as the most innovative Persian poem which reveals considerable similarity with Musset's 'Nights' (1973, p.312).

However, this point should be stressed that Nima's relation with French romanticism never situated him in a place of a mere copy writer whereas his innovative mind used this new window for flourishing his own perspective in Persian context. Indeed, "Nima has masterfully mingled the spirit of French romanticism with oriental perspective in 'Afsaneh' "(Zarinkoob, 1973, p.312).

Based upon the various study conducted on Nima's romanticism, no doubt is left that Nima is the most romantic (in the tradition of European romanticism) poet and his poem 'Afsaneh' is the prototype of this view. Therefore, our aim is to study this poem more closely based on Abrams' theoretical essay which has coined the term "greater romantic lyric" to portray the tradition in which the notable exemplars of English romanticism wrote their poems. As a result, we try to prove Nima's 'Afsaneh' is also following the same tradition.

\section{Nima's 'Afsaneh' as an exemplar of the Greater Romantic Lyric}

As it was mentioned above, Abrams traces the evolution of romantic lyric from seventeenth century up to the mid-eighteenth century. In his famous essay, he was sensitive enough to detect that the genre of lyric and ode have come so close to each other that they had formed a new genre in the hands of the great English romantic poets like Wordsworth, Coleridge and Keats etc. and he raises the question if ode is actually the source from which the lyric poetry is developing; "Some of the poems are called odes, while the others approach the ode in having lyric magnitude and a serious subject, feeling-fully meditated"(1965, p.201). In fact, these two genres of poetry seem to have some common parts. If we refer to Abrams' Glossary of Literary Terms, lyric poetry is defined as "any fairly short poem, uttered by a single speaker, who expresses a state of mind or a process of perception, thought, and feeling" (2004, p.179) and under the definition of the ode, is written "'ode' denotes a long lyric poem that is serious in subject and treatments, elevated in style, and elaborate in its stanzaic structure"(2004, p.235).

Upon observing these definitions, we could conclude that these two forms are highly interconnected though it is rather difficult to determine which one is developed out of the other one. And as Abrams analyzed the English romantic poets, he observed that not only have these two genres come so closely to each other but also they are affected by the outer descriptions and the internal state of consciousness. Therefore, according to Abrams, this new genre "synthesizes descriptions of the external world and internal states of consciousness, expresses a union of mind with nature, or of mind over nature" (Koelzer, 2006, p.67). 
For Abrams, the interaction of mind and nature is of immense importance. Because he believes that this interaction actually forms the poem, "repeated out-in-out process, in which mind confronts nature and their interplay constitutes the poem"(1965, p. 202). At this juncture, Abrams felt obliged to coin a term for this new genre in which the romantic poets had been writing their poems. Thus he labeled this new genre as 'the greater romantic lyric' and tries to justify his decision in this way:

I shall call this poetic type 'the greater Romantic lyric,' intending to suggest. . .that it displaced what neoclassical critics had called 'the greater ode' -the elevated Pindaric, in distinction to 'the lesser ode 'modeled chiefly on Horace - as the favored form for the long lyric poem(1965, p. 202).

Later on, Abrams focuses on pointing out the features of this new poetic form by analyzing such poems as Coleridge's "The Eolian Harp" and "Fears in Solitude," and Wordsworth's "Tintern Abbey". Then he fully explicates this new poetic form in his critical essay, "Structure and Style in the Greater Romantic Lyric", as follows:

They present a determinate speaker in a particularized, and usually a localized, outdoor setting, whom we overhear as he carries on, in a fluent vernacular which rises easily to a more formal speech, a sustained colloquy, sometimes with himself or with the outer scene, but more frequently with a silent human auditor, present or absent. The speaker begins with a description of the landscape; an aspect or change of aspect in the landscape evokes a varied but integral process of memory, thought, anticipation, and feeling which remains closely intervolved with the outer scene. In the course of this meditation the lyric speaker achieves an insight, faces up to a tragic loss, comes to a moral decision, or resolves an emotional problem. Often the poem rounds upon itself to end where it began, at the outer scene, but with an altered mood and deepened understanding which is the result of the intervening meditation (1965, p.527-528).

Now, we shall examine this definition more closely and see how Nima's "Afsaneh" fits this definition. Before delving into the poem and analyzing it with respect to Abrams' classification, it is noteworthy to take into account Nima's preface of this poem. He wrote a preface to this poem, in addressing to a mysterious "young poet" who is most likely Nima's friend Mirzadeh Eshaghi. In his preface, he has tried to elaborate on one specific subject which is of our great concern. He says:

This structure that my Afsaneh has been placed in, and which demonstrates a natural and free-flowing style of conversation, may not appeal to you at first, and you may not like it as much as I do. Also, you might ask why a ghazal should be so long and the words used in it so light, compared to the ghazals of the classical poets? Yet, this is precisely what I meant to accomplish: freedom in expression and the lengthening of the discourse... (Nima, 2011, p.36)

The degree of the similarity between Nima's preface and Abrams' definition is striking. This could be easily seen that Nima himself knew that he had been creating a unique form of writing poetry in comparison with the great classical tradition of Persian poetry. As he refers to the both colloquial style and length of his poem, he is actually acknowledging that he is not writing in the classical tradition. He simply defends his deviation from the classical tradition by professing the urgent need of Persian poetry for a "freedom in expression". Probably he is not aware of the fact that he is writing in the norm of the European romantic poets especially the English romantic poets such as Wordsworth and Coleridge.

Now, apart from Nima's justification of "Afsaneh", we should try to analyze Nima's "Afsaneh" with respect to Abrams's viewpoint. For the first part, Abrams emphasizes the existence of a 'determinate speaker' who speaks 'in a fluent vernacular' while he is in 'localized, outdoor setting' addressing an 'auditor'. And the speaker begins by 'describing a landscape'. "Afsaneh" exactly begins and develops in this way. The poem is initiated when a speaker named "Afsaneh" starts talking about a lover who 
has been left alone in a vale. Likewise, we have a speaker who starts talking with reference to an outdoor setting:

Afsaneh says: In the somber night, a madman who

Has committed his heart to a fleeting hue

Is sitting in a clod, quiet vale

Like the stem of a withered plant

He begins a sorrowful tale (Nima, 2011, p.39)

Then the poem continues by a conversation between Afsaneh and the lover. This could be considered as the sole point of difference between Nima's 'Afsaneh' and the poetic style explained by Abrams in his essay. Because in the examples cited by Abrams, there is only one speaker though the existence of a silent listener can be easily felt. Nonetheless, this slight difference can be neglected as the structure of the whole poem abides by Abrams' definition. Therefore, the poem continues in this way until 'change of aspect in the landscape' causes the evocation of a strong feeling of past memory in both the lover and 'Afsaneh':

Lover says: Yet the wave that move on turbulent

Carry on its lip a tale about you

Your lips were smiling in that wave

Afsaneh says: I saw on that agitated wave

A hectic lone rider

Lover says: But I reach a rose-face beauty

Her hair entangled like an enigma

Like a restless whirlwind (Nima, 2011, p.41-42)

Lover says: Oh Afsaneh, Afsaneh, Afsaneh

I am the target of your arrow

Remedy of the heart, medicine for pain

For my nocturnal cries

What do you mean to do with me, so scourged?

And what are you, you hidden from my view. (Nima, 2011, p. 42)

As the lover and Afsaneh keep on talking about each other, they are extended into a deep meditation on their past memories. Suddenly, a change is occurred in the outer scene. As the lover mentions a turbulent wave which carries a message on its lips. The description of this turbulent wave provides a contrast with the previous serene atmosphere of the poem. As a result, the occurrence of this change (from a serene atmosphere to harsh one) evokes an integral process of feeling which leads to a flash of insight. At this part of the poem, the insight is produced when the lover cries "Oh Afsaneh, Afsaneh, Afsaneh" (Nima, 2011, p. 42) and it is followed by 'a tragic loss' when the lover says "I am the target of your arrow"(Nima, 2011, p. 42). The last part shows that a huge unbridgeable gap is created between the lover and Afsaneh. This part of the poem fully conforms to Abrams' definition. As Abrams mentioned the inter-involvement of the poet and the nature and if any change is introduced in the nature, it is reflected in the human feeling. The same is clearly shown in the poem. 
This uneasy feeling between the lover and Afsaneh remains throughout the poem. And each time it is expressed in relation with the outer world. In one part of the poem, Afsaneh expresses their intense relationship with reference to the dreadful nights:

Afsaneh says: O there were so many dreadful nights?

When from behind the clouds appeared

A figure you did not recognize

In a sad heart-rendering voice

It whispered my name in the depths of your ears

I am that same stranger, O lover! (Nima, 2011, p. 49)

As it is clear, the uneasy feeling is backgrounded in the description of the dreadful nights which is covered behind clouds. And suddenly a figure is appeared out of this cold and frightening situation to say that Afsaneh is a stranger to the lover. A lover and beloved, whose relationship should be warm and attractive, are so distanced from each other that they seem like strangers. This tragic insight is well portrayed with reference to the dreadful nights.

The last part of Abrams' definition of "the greater romantic lyric" emphasizes that the poem should end where it started. In other word, it should round up in the same outer scene and the only thing altered should be the speaker's mood. In this case, the speaker basically acquires a deeper understanding of his emotional problem. Likewise, in "Afsaneh", the poem ends when the lover has gained a deeper understanding of his situation and he is expressing his sadness in calm. This is clear in his reference to the outer scene. Moreover, the poem ends in exactly the same setting where it started:

Lover says: Hide me behind the clouds

So none but an angle should

Hear my voice in the heaven

So none may read these words

But a lamenting lover

Leave my teardrops on her cheeks

Echo my lament in her heart

Take my nameless soul there

Where sounds of wailing

Rise from that burning heart

Oh, come forth from this narrow vale

For it is the Shepard's best resting place

For no one knows the way here

So here, where everything is alone

We may sing together in our melancholy "(Nima, 2011, p. 70-71)

As one can see, lover' emotional problem is not resolved though he has gain a deeper understanding of his situation. Even he tries to advise other lamenting lovers what to do. Moreover, as it was mentioned above, the poem ends exactly where it started. It started from a "cold and quiet vale" and ends in a "narrow vale". This poem unlike the love poems which ends in the happy union of the lover and beloved concludes with the mourning of the lover who tries to sing his melancholy songs along with other lamenting lovers in a narrow vale. 
One of the basic elements of this poem is the lover's meditation over his emotional problem. Not only does the poem starts and ends with lover pondering over his problem but also this meditation is sustained throughout the poem and is always aligned with the description of the outer scene. This is exactly what Abrams has emphasized when he indicated that "The description is structurally subordinate to the meditation, and the meditation is sustained, continuous, and highly serious" (1965, p. 224). Based on our close observation of Nima's "Afsaneh", our conclusion could be clear and obvious that Nima's "Afsaneh" fully conforms to the genre of "greater romantic lyric" coined by Abrams. Indeed, Nima is truly writing in "a distinctive and widely practiced variety of the longer Romantic lyric (1965, p.224)".

\section{CONCLUSION}

In 1922, Nima's "Afsaneh" was first published in installments. His poem was the beginning of a drastic change in the long-standing tradition of classical Persian literary history. In fact, he launched "his lonely crusade to modernize Persian poetry in the face of solid opposition from an assortment of social forces opposed to the new poetry"(Karimi-Hakkak, 1995, p.2). Regarding the genre of his poem, probably Nima was not aware into what tradition he had been following, even though; he has acknowledged his deviation from the old-established classical Persian literary history.

Through this study, it was tried to seek a poetic style for this truly bizarre poem which has open a new tradition and style in the Persian literary history. And we could resolve this problem by referring to the Abrams' critical essay entitled "Structure and Style in the Greater Romantic Lyric". In his essay, Abrams has analyzed some of the long poems of English romantic poets like Coleridge, Wordsworth, and Keats etc. and has pointed out some basic features for these poems. Then he concluded that during the English romantic period, the great romantic exemplars have devised a new method for writing their poetries. Thus Abrams coined the term "the greater romantic lyric" for the genre in which English romantic poets have written their poems.

When we studied Nima's "Afsaneh" and its preface through the lenses of Abrams' view of English romantic poems, we observed that this poem closely matches Abrams' definition of the "greater romantic lyric" and concluded that this bizarre poem in the tradition of Persian literary history has been written following the tradition of the genre "greater romantic lyric". Vahabzadeh, a well-known Nima critic, once mentioned that "paying true homage to Nima Yushij is possible through offering a different reading of his poetry" (2004, p.193). In this case, we also tried to fully pay our respect to the father of modernist Persian poet by reading one of his greatest poems differently.

\section{References}

[1] Abrams, M. H. (2004) Glossary of Literary Terms, (8th ed.), United States: Earl McPee.

[2] Abrams, M. H. (1965). "Structure and Style in the Greater Romantic Lyric", in From Sensibility to Romanticism: Essays Presented to Frederick A. Pottle, New York: Oxford University Press, pp. 527-28.

[3] Arianpour,Y. (2008) From Saba to Nima, Tehran: Zavar.

[4] Burgum, B. A. (1941). "Romanticism". The Kenyon Review, Vol. 3, No. 4, pp. 479-490. http://www.jstor.org/stable/4332291

[5] Chandler, J. K. (2009), "Romantic Allusiveness", Essays in Romanticism, Vol. 17, Issue. 1, pp. 101-131. http://online.liverpooluniversitypress.co.uk/doi/pdf/10.3828/EIR.17.1.5

[6] Ja'fari, Mas'ood (2007). From Constitutional Revolution to Nima Yushij. Tehran: Nashre-e Markaz. 
[7] Karimi-Hakkak, A. (1995). Recasting Persian Poetry: Scenarios of Poetic Modernity in Iran, Utah: University of Utah Press.

[8] Karimi-Hakkak, A. Talattof, K. (Eds.). (2004), Essays On Nima Yushij: Animating Modernism In Persian Poetry, Boston: Brill Press.

[9] Koelzer, R. (2006), "Abrams Among the Nightingales: Revisiting the Greater Romantic Lyric", The Wordsworth Circle, Vol. 37, No. 2, pp. 67-71. http://www.jstor.org/stable/24044130

[10] Lindenberger, H. (2009). "Theories of Romanticism: From a Theory of Genre to the Genre of Theory", Essays in Romanticism, Vol. 17, Issue. 1, pp. 27-51. http://online.liverpooluniversitypress.co.uk/doi/pdf/10.3828/EIR.17.1.2

[11] Lovejoy, O. A. (1962). "On the Discrimination of Romanticism". In Romanticism: Points of View. Ed. Gleckner\& Enscoe. London: Prentice Inc, (pp. 229-253), http://www.jstor.org/stable/457184.

[12] Tahbaz, S. (Eds.). (2011), The Complete Works of Nima Yushij, Tehran: Ghalam Institution.

[13] Wellek, R. (1949). "The Concept of 'Romanticism' in Literary History II. The Unity of European Romanticism". I. The Term "Romantic" and Its Derivatives, Comparative Literature, Vol. 1, No. 2, pp. 147-172. http://www.jstor.org/stable/1768325.

[14] Zarinkoob, A. H. (1973). Not Oriental Nor Occidental, Tehran: Amirkabir. 